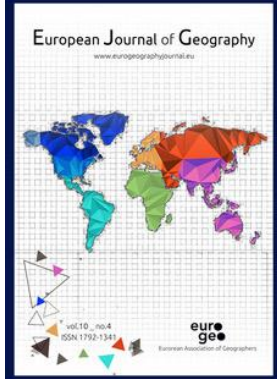

European Journal of Geography

Volume 11, Issue 2, pp. 047 - 064

Article Info:

Received: 03/09/2020; Accepted: 12/12/2020

Corresponding Authors: * hgekic@gmail.com

https://doi.org/10.48088/ejg.h.gek.11.2.47.64

\title{
Hidden geographies of population implosion in Bosnia and Herzegovina
}

\author{
Haris GEKIC ${ }^{*}$, Aida BIDZAN-GEKIC ${ }^{1}$, \\ Ranko MIRIC ${ }^{1}$, Peter REMENYI ${ }^{2}$
}

${ }^{1}$ University of Sarajevo, Bosnia and Herzegovina

${ }^{2}$ University of Pécs, Hungary

\section{Keywords:}

hidden geographies, depopulation, emigration, population ageing, system of values, Bosnia and Herzegovina

\begin{abstract}
Bosnia and Herzegovina has witnessed continuous depopulation since 1991. Depopulation was foreseen even without the emergence of war, but not nearly to that extent or that early. Bosnia and Herzegouina is in a worse demographic position than the European Union countries that show similar demographic trends. Very low birth rates, low fertility and low natural population growth have been recorded in the time of weaker economic development, which increasingly accelerates the emigration of the educated population in particular, and permanently adversely affects the reproductive potential of the country. This paper considers a hidden mutual relationship between the demographic situation (natural change, population ageing) in Bosnia and Herzegovina and its citizens' system of values. According to the survey conducted on 614 respondents, Bosnia and Herzegovina's citizens have fewer children than they would like.
\end{abstract}

The publication of the European Journal of Geography (EJG) is based on the European Association of Geographers' goal to make European Geography a worldwide reference and standard. Thus, the scope of the EJG is to publish original and innovative papers that will substantially improve, in a theoretical, conceptual or empirical way the quality of research, learning, teaching and applying geography, as well as in promoting the significance of geography as a discipline. Submissions are encouraged to have a European dimension. The European Journal of Geography is a peer-reviewed open access journal and is published quarterly. 


\section{INTRODUCTION}

According to the latest (2013) Census, Bosnia and Herzegovina had a population of $3,531,159$. According to the statistical institutes' estimates, there was a total of $3,414,161$ inhabitants in Bosnia and Herzegovina at the end of 2019, showing a decrease of $3.3 \%$. As much as $18 \%$ of the active population is engaged in agricultural activities, and more than half of the total population live in rural areas (BHAS, 2016; FZS, 2019a; ISR, 2019a).

National and regional policies addressing the population implosion remain either non-existent or non-effective, due to the lack of will or due to ignorance and a lack of evidence. This will, in our opinion, lead to earlier and more unfavorable population implosion in Bosnia and Herzegovina. The data and their analysis presented in this paper demonstrate that there are hidden geographies of population implosion, which are not included in various strategies and programmes at the state level. The majority of citizens' social values concerning population implosion characteristics, especially in young age groups (15-29), remain increasingly hidden and ignored by the public, and by politicians and regional and local governments in particular.

Depopulation is evident in the whole territory of the Western Balkans, especially in the last decade (Lukic et al., 2012), but it is the most prominent in Bosnia and Herzegouina. Bosnia and Herzegouina is facing a depopulation process, which is mostly caused by emigration, decreasing birth rates, increasing death rates and population ageing. Unfortunately, there is no institutionalized population policy in this country which could lead to demographic revitalization (Kadušić and Suljić, 2018). According to Halilovich (2012), Bosnians nowadays represent one of the most widespread emigrant communities from the Balkans. The recent post-war demographic situation and fertility behaviour in Bosnia and Herzegovina share some similar characteristics with those outlined in the second demographic transition theory and commonly applied to European countries (uan de Kaa, 1996; Lesthaeghe and Neels, 2002; van Bavel, 2007).

The expression "demographic/population implosion" must be handled with care because, while it is true that in Europe there is a decrease in the proportion of youth, this decline will produce its effects (population ageing and a decrease in natural growth) very slowly (Dumont, 2006). Population ageing poses an even greater challenge to the post-communist societies of Central and Eastern Europe (Hoff, 2011). Unfauourable processes and structural features (similar to Croatia) characterize Bosnia and Herzegovina's current demographic development: general depopulation, depopulation of most administrative territorial units, reproductive depopulation, ruralurban dichotomy, accelerated ageing and a very high proportion of the elderly population (Gelo et al., 2005; Nejašmić, 2008). The above mentioned interdependent elements of the demographic development, along with the most important factorsemigration and war, have shaped a very uneven distribution and development of the population (Nejašmić and Toskić, 2000). The differences are particularly large and significant between urban and rural areas, and between distinctly urban and rural municipalities (Friganović, 1992; Akrap, 2002). Similarly, Georgia has also witnessed a decrease in population and natural increase rate, and a growing imbalance in the gender and age structure (Putkaradze et al., 2019).

Only the capital, Sarajevo, has more than 250,000 inhabitants. In the last decade, the process of urbanization has slowed down, while suburbanization has occurred 
mainly in the vicinity of major cities such as Sarajevo, Banja Luka, Mostar and Zenica. The population is ageing very fast and life expectancy is increasing, which raises concerns about the demographic trends. Negative migration rates have been characteristic since the late 19th century; not even the rapid industrialization and urbanization in the period 1965-1980 stopped the emigration of the Bosnian population. Emigration increased to an unprecedented scale during the 1992-1995 war. Bosnia and Herzegovina is an ethnically and religiously heterogeneous country. Ethnic Bosniaks make up more than half of the population, Serbs almost one third, and Croats just over one seventh. Muslims, also in the religious structure of the population, constitute more than half of the total population (BHAS, 2016). Between 1948 and 1981, the population of Bosnia and Herzegovina increased by approximately $61 \%$ or at an average annual rate of $1.8 \%$. By 1991, the number was growing at an average annual rate of $0.6 \%$. According to the estimate of the national statistical institutes, the number of inhabitants after the war (1992-1995), in 1996, was lower by $16.7 \%(732,033)$. According to the data from the most recent (2013) census, the population in Bosnia and Herzegouina was $19.3 \%$ lower than at the penultimate census in 1991-bearing in mind that the last census was made according to the de facto population concept compared to the previous censuses, which used the de jure population concept (BHAS, 2018).

In 2019, the average population density in Bosnia and Herzegovina was 66.7 inhabitants $/ \mathrm{km}^{2}$ compared to 85.5 inhabitants $/ \mathrm{km}^{2}$ in 1991. Due to Bosnia and Herzegouina's very dynamic terrain and dissected relief in the central area, and flatlands in the northern and southern parts, its population is unevenly distributed. The most densely populated area is the Sarajevo-Zenica Basin with about 230 inhabitants $/ \mathrm{km}^{2}$, and the least densely populated is the area of the Bosnian High Karst in the west of the country with less than 16 inhabitants $/ \mathrm{km}^{2}$. Most of the population of Bosnia and Herzegouina live in the central parts, while the marginal parts of the country (except for the far northwest and northeast) are sparsely populated. Bosnia and Herzegovina has always had a lower rate of urbanization. Sarajevo is the only urban settlement with a population of more than 200,000 (i.e. 271,194), and the only other urban settlement that comes even remotely close to this number is Banja Luka $(138,963)$. Only 12 urban settlements have more than 20,000 inhabitants. The urban structure is dominated by micro-urban settlements or micro-cities with less than 5,000 inhabitants, which account for $39 \%$ of the total number of urban settlements (Gekić et al., 2019a).

\section{MATERIAL AND METHODS}

The population implosion trends in Bosnia and Herzegovina were analysed and determined using secondary data from the country's statistical offices and applying many demographic indicators, such as birth rates, fertility rates, mortality and natural population change rates, marriage rates, average age, ageing index, migration net balance, etc. Spatial differentiation of several demographic indicators within Bosnia and Herzegovina was shown by maps created with ArcGIS application. Changes in the total number of Bosnian population between censuses were calculated as a difference between the two censuses divided by the number of inhabitants from the previous census, in absolute and relative numbers (Wertheimer-Baletić, 1982). 
From secondary data about live births, we calculated differences between different periods using absolute numbers, relative numbers (in percent), and average rates. We calculated the proportion of deaths in people under the age of 65 , separate for males and females, and crude marriage rates using secondary data about the number of marriages and the total number of inhabitants. The causes and characteristics of population implosion trends in Bosnia and Herzegovina are discussed and compared with European countries. To show essential characteristics of the natural movement of the population within Bosnia and Herzegovina, we performed spatial differentiation at the level of municipalities, considering the average birth rates, mortality rates, rates of natural change, and marriage rates over a five-year period, 2014-2018. We divided all municipalities into five groups based on the above-mentioned rates (Brčko District was counted as one municipality).

In this paper, we have considered hidden geographies between the population implosion in Bosnia and Herzegovina and the system of values of its citizens on the basis of several surveys conducted in recent years, including our survey. Through the survey we tried to find the most important hidden reasons for the population implosion in Bosnia and Herzegovina, which are not clearly visible from the data auailable or from the media and media coverage of specific organizations and agencies. The purpose of the study was to contribute to the understanding of hidden characteristics of the population implosion in Bosnia and Herzegovina by analysing the system of values of its citizens and thus help confirm the general assumptions about the said population implosion. The focus is on a more detailed examination of the current situation, based on the data from the last census (2013) and the period 2014-2018, which was used for spatial differentiation analysis. In the period February-May 2019, we surveyed a sample of 614 respondents. Out of the total number of respondents, most (324 or $52.7 \%$ ) are in the age group of 15-29 years, which suited our goal to find out the opinion of the most potent part of the population on these issues. To select a representative random sample of respondents in Bosnia and Herzegovina, we used the data on the number and population structure of the (most recent) 2013 census at the municipal level. We then determined a stratified random sample. We stratified the following indicators on municipalities: share of the young population, type (group) to which the municipality belongs regarding the birth rate, GDP per capita, degree of urbanization, and type of ethnic and religious structure of the municipality. The sample was also stratified according to the size (population) of municipality into 7 categories: micro (up to 3,000$)$, very small $(3,001-7,000)$, small $(7,001-12,000)$, medium-small $(12,001-20,000)$, medium-sized (20,001-30,000), large $(30,001-50,000)$, and very large (over 50,000 inhabitants). Out of the total of 614 respondents, 55\% were from rural and $45 \%$ from urban municipalities. By gender, 53\% were women and $47 \%$ were men. In the discussion, we specifically looked into issues relating to hidden existential assumptions of population implosion in Bosnia and Herzegovina to provide a more complex analysis.

\section{RESULTS AND DISCUSSION}

Since the early 1990s, there has been a marked shift in circumstances for reproductive behaviour in Bosnia and Herzegovina-from a more or less stable socio-economic and 
living environment to more impoverished conditions with regard to each segment of life, especially during the war itself, but also in the post-war period (Helms, 2013; Vuillamy, 2012). The Bosnian population is an old population, although not as much as in the developed countries of the world (20.5\% of the population is over 60 years old). The ageing index (number of elderly aged 60 and over per hundred young people aged 0-19) in 2013 is 92.2 and is almost half higher than in the previous census (63.3 in 1991). Evidently, in Bosnia and Herzegouina there are far more older people now than in 1991 and their share is almost equal to the share of young people (Gekić et al., 2019b). Population ageing has primarily resulted in a decrease in fertility rates in the late 20th century and in an increase in life expectancy. The rapid decline in fertility rates in developed countries was linked to the demographic transition from higher to lower fertility and mortality rates. In Bosnia and Herzegouina, this occurred during the 1970s. According to the 1948 census, the birth rate in Bosnia and Herzegovina after the Second World War was about 35\%, and in the next 30 years, it decreased twice in number to $17.7 \%$. In 1991, the birth rate was moderate 14.9\%o (Figure 1). At the same time, overall fertility rates decreased very rapidly, from 5 children born per woman in the fertile period in 1948, to 3 in 1960, 3 in 1967, and 2 in 1978. In 1991, this rate was 1.9 children born per woman, which was not enough for the simple reproduction of the population (BHAS, 1948-1991).

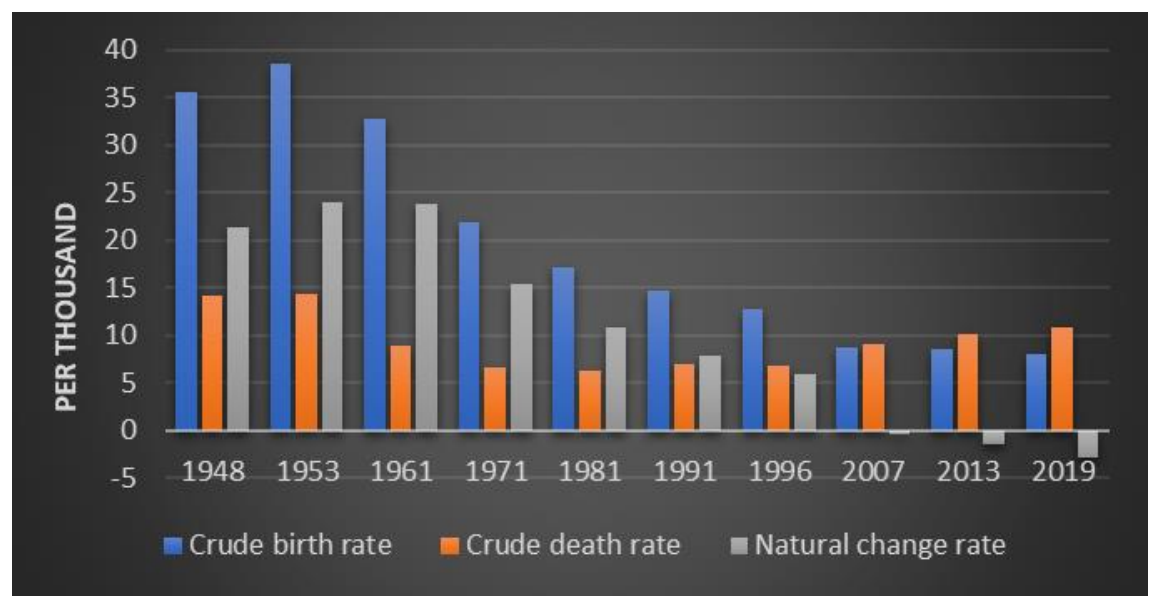

Figure 1. Natural change rates in Bosnia and Herzegovina, 1948-2019

After the Second World War, the birth rate declined in line with the transition of the active population to other sectors outside agriculture. Married couples, therefore, wanted fewer children; longer education process and increased female employment were important factors as well. In the year before the last war, in 1991, the number of live births reached 65,430, and it has been in decline ever since. For the period 19921995 , there is no information on this trend. The number of live births in 1996 was $28.8 \%$ lower than in the pre-war year of 1991. Between 1996 and 2019, the number of live births decreased by as much as $41.6 \%$ or 19,385 (at an average annual rate of $-1.8 \%$ ). The lowest number of live births was 27,209 in 2019 and was nearly 3,000 lower than in 2017, which amounts to approximately 10\% (BHAS, 2019). This represents a critical turning point and a worrying phenomenon for the population of Bosnia and Herzegovina. The total fertility rate is $\mathbf{1 . 2 6}$ children born per woman. It is one of the 
lowest in the world, immediately after Singapore and South Korea (World Factbook, 2019).

Mortality rates only began to decrease below 10\% after the $1950 \mathrm{~s}$ due to improvements in health care and living conditions. It was the lowest in 1974, at just $6 \%$, and then slowly grew. After 1995, due to increasing population ageing, the mortality rate increased to $10.9 \%$ in 2019 . The death toll today is almost equal to that in the 1950s. At the same time, life expectancy at birth has increased: men born in 1961 lived to be 59 years old and women 63, whereas men born in 2019 have a life expectancy of 76 years and women of 80 years (BHAS, 1948-1991; BHAS, 2019). The average age of the female population at the time of death in 2018 was 77 years and of the male population 71. In Bosnia and Herzegovina, just over $22 \%$ of deaths occur to people younger than 65 years old. Death before the age of 65 is much more common among male residents (as much as $28 \%$ of total male deaths), while it is significantly less in the female population (16\%). On average, $90 \%$ of the population die from circulatory system diseases, neoplasms, and endocrine and metabolic disorders (BHAS, 2019; BHAS, 2017).

Longer life expectancies at birth, declining birth rates, and an ageing population have led to extreme changes in the rate of natural change in the population. This was all exacerbated by the great wave of emigration and casualties during the 1992-1995 war. The total number of casualties in the war in Bosnia and Herzegovina is estimated by the UN-verified ICTY (The International Criminal Tribunal for the former Yugoslavia) experts to be 104,732 , of which $40 \%$ are civilians, and by ethnicity, $65 \%$ are Bosniaks. Ethnic cleansing processes and more than 2 million people displaced resulted in a major shift in the development of the population of Bosnia and Herzegovina (Zwierzchowski and Tabeau, 2010).

In Bosnia and Herzegovina, natural population change has been declining since the mid-1950s, when it moved from high rates (above 25\%0) to moderate ones. This rate continued to decline and in the early 1970s reached a low level. In the mid-1980s, natural change rate dropped to below $10 \%$ as a result of a large decline in the birth rate. After 1995, the rate of natural change continued to decrease from 5.9\%o in 1996 to the first negative rate of $-0.3 \%$ in 2007 , after which it continued to decline. In 2019, the rate of natural change in the population of Bosnia and Herzegovina was negative (2.9\%o). The average maternal age at birth of the first child has increased from 22 years in 1991 to almost 28 years in 2019. Marriage rates have been declining gradually since 1948, when it was $13 \%$, then in 1991, when it was $6.6 \%$, and to $5.8 \%$ in 2018. (BHAS, 1948-1991; BHAS, 2019). Compared to 1948, the number of marriages decreased by $41 \%$, while the number of children born out of wedlock in 2017 is still very low compared to the countries of the European Union. In 2017, it was around $11 \%$, while in Slovenia, this share was around 20\% (BHAS, 2017; SURS, 2017).

Spatial differentiation in terms of the birth rate in Bosnia and Herzegovina is dominated by municipalities with low rates (7.1-10.0\%o), namely 64 or $44.8 \%$. This group of municipalities is very heterogeneous and is represented by municipalities from almost all parts of the country except for the far west and east, where the population is predominantly older (e.g. Istočni Stari Grad and Vlasenica in Eastern Bosnia). This group of municipalities fits within the Bosnia and Herzegovina average of $8.4 \%$ (Table 1). 
Table 1. Classification of municipalities by birth, death and natural change rates 2014-2018 in \%o

\begin{tabular}{|c|c|c|c|c|c|}
\hline $\begin{array}{l}\text { Birth } \\
\text { rate }\end{array}$ & $\begin{array}{l}\text { No. } \\
\text { municipalities }\end{array}$ & $\begin{array}{l}\text { Death } \\
\text { rate }\end{array}$ & $\begin{array}{l}\text { No. } \\
\text { municipalities }\end{array}$ & $\begin{array}{l}\text { Natural change } \\
\text { rate }\end{array}$ & $\begin{array}{l}\text { No. } \\
\text { municipalities }\end{array}$ \\
\hline 0 & - & $0.1-5.0$ & 2 & $<-10.0$ & 17 \\
\hline $0.1-4.0$ & 20 & $5.1-10.0$ & 54 & -10.0 to -5.1 & 27 \\
\hline $4.1-7.0$ & 38 & $10.1-15.0$ & 66 & -5.0 to -0.1 & 75 \\
\hline $7.1-10.0$ & 64 & $15.1-20.0$ & 15 & $0-2$ & 15 \\
\hline$>10.0$ & 21 & $>20.0$ & 6 & $2.1-5$ & 9 \\
\hline
\end{tabular}

Source: calculated from the data FZS, $2019 \mathrm{~b}$ and ISR, $2019 \mathrm{~b}$

The second most widespread group of municipalities are those with a very low birth rate $(4.1-7.0 \%)$ and account for $26.6 \%$ of the total number of municipalities. These are municipalities with a higher proportion of the elderly (more than $20 \%$ aged 60 years or more); since the 1970s, these have mainly been municipalities from which the population emigrated for economic reasons (e.g. Vukosaulje and Kupres FBiH). The third-largest group has an average birth rate (10.1-15.0\%o) and is made up of 21 municipalities or $14.7 \%$ of the total number of municipalities. This is a group of municipalities with propulsive development (e.g. Ilijaš and Trebinje). The fourth-largest group are municipalities with extremely low birth rates (below 4\%), which make up $14 \%$ of the total number. These are municipalities that are generally small in population and large in area (FZS, 2019b; ISR, 2019b); they have a high emigration rate and a high proportion of the elderly (e.g. Lopare and Rauno). There are no municipalities in the fifth group, without live births (Figure 2).

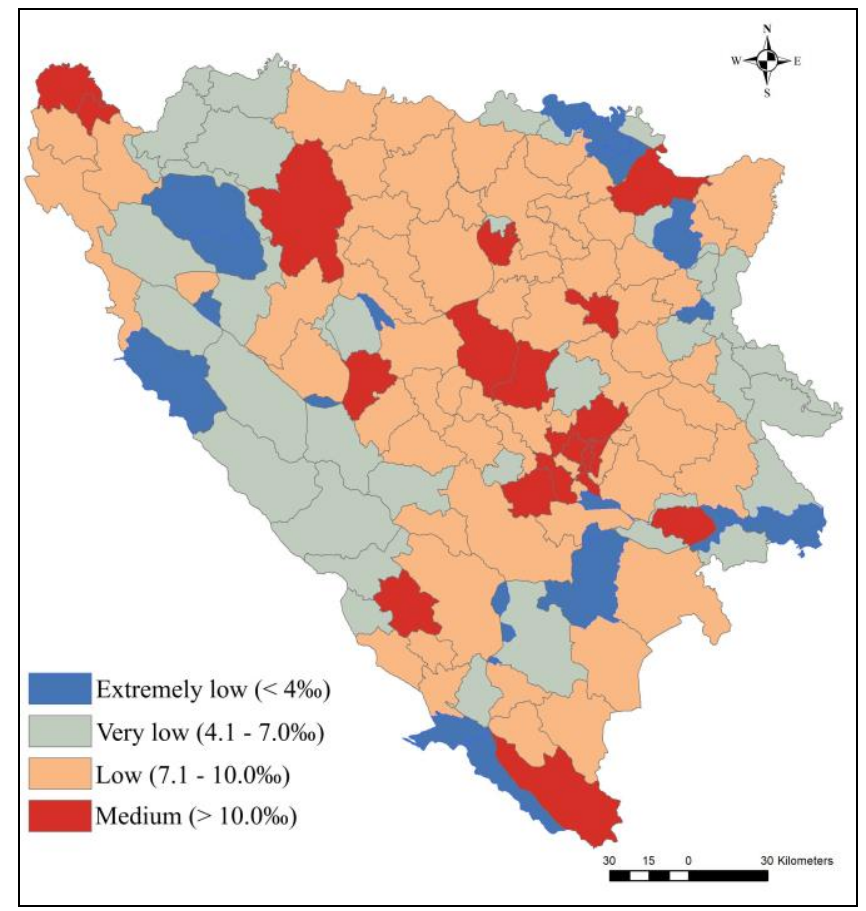

Figure 2. Municipalities by birth rate, 2014-2018

The spatial differentiation of mortality rates in Bosnia and Herzegovina is much more uniform than the differentiation according to the birth rate. Two groups, with low and medium mortality rates, account for $84 \%$ of all municipalities. Both of these groups of municipalities are very heterogeneous, the difference being that the group of municipalities with an average mortality rate $(10.1-15.0 \%)$ is dominated by those in 
which the older population amounts to over $20 \%$. The third largest group consists of municipalities with high mortality rates (15.1-20.0\%0), which make up $10.5 \%$ of the total number of municipalities. These are mostly emigrant municipalities with a high proportion of the elderly (average 25-35\%). Six municipalities in Bosnia and Herzegovina form a group with a very high mortality rate, 20.1-30.0\%o (FZS, 2019b; ISR, 2019b). Five of them emerged as a result of the Dayton Peace Agreement, by separating some rural areas from the municipalities which were characterized by a higher proportion of the elderly than the young (Oštra Luka, Petrovac, Istočni Stari Grad, Krupa na Uni and Trnovo $\mathrm{FBiH}$ ). The extreme group with the lowest mortality rate (up to 5.0\%) includes only two municipalities: Rauno with 3,190 inhabitants and Istočni Mostar with 243 inhabitants (Figure 3).

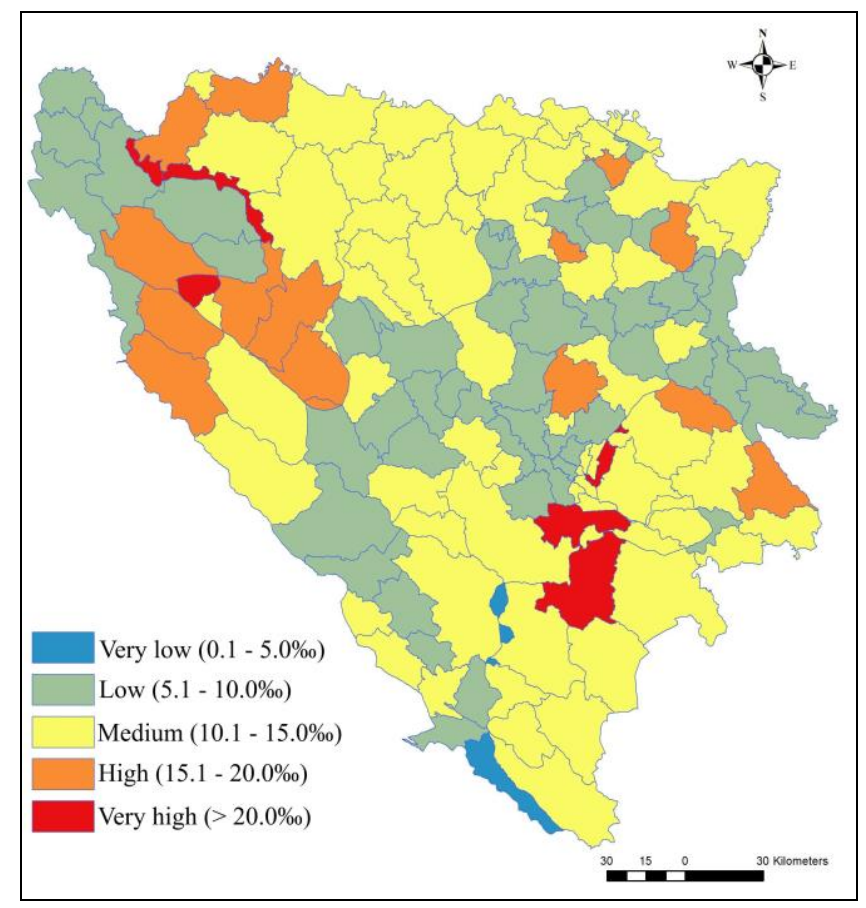

Figure 3. Municipalities by mortality rate, 2014-2018

The spatial differentiation of the rate of natural change shows the dominance of municipalities with a negative rate of natural change. Of the total number of municipalities, $83.2 \%$ have a negative rate of natural change. The largest group, with a rate of -5.0 to $-0.1 \%$, is characterized by a very low natural decrease in population (75 municipalities or $52.4 \%$ ). These numbers are sufficient evidence of the prevalence of natural depopulation in Bosnia and Herzegovina. While these are very heterogeneous municipalities in terms of size, economic, and urban development, they have a similar percentage of the old population, which is above $20 \%$ on average. Municipalities with a low natural decrease make up $19 \%$. These are extremely old municipalities regarding age structure and are located mainly at the outer edge of the country. They are characterized by emigration, a higher proportion of the old population, and poor economic development (FZS, 2019b; ISR, 2019b). There are 9 municipalities with a very low rate of natural population change, in which the birth rates exceed the death rate by at least 2 \%o (Doboj-Jug, Velika Kladuša, Hadžići, Ilidža, Banouići, Tešanj, Vogošća, Ilijaš, and Bužim). These municipalities are very similar in terms of economic 
development, degree of urbanization and age structure, although they differ in the population size. The municipalities of Velika Kladuša and Bužim have a significant number of residents working in the EU countries whose families are left at home. The municipalities of Hadžići, Vogošća, and Ilijaš are developing under the agglomeration influence of the capital Sarajevo, while Tešanj and Doboj-Jug have taken advantage of their favourable geographical position and have even managed to become immigration municipalities with a large set of economic measures at the local level. Municipality of Banouići has been a mining municipality for more than $\mathbf{7 0}$ years, where coal mining provides incentives for population development (Figure 4).

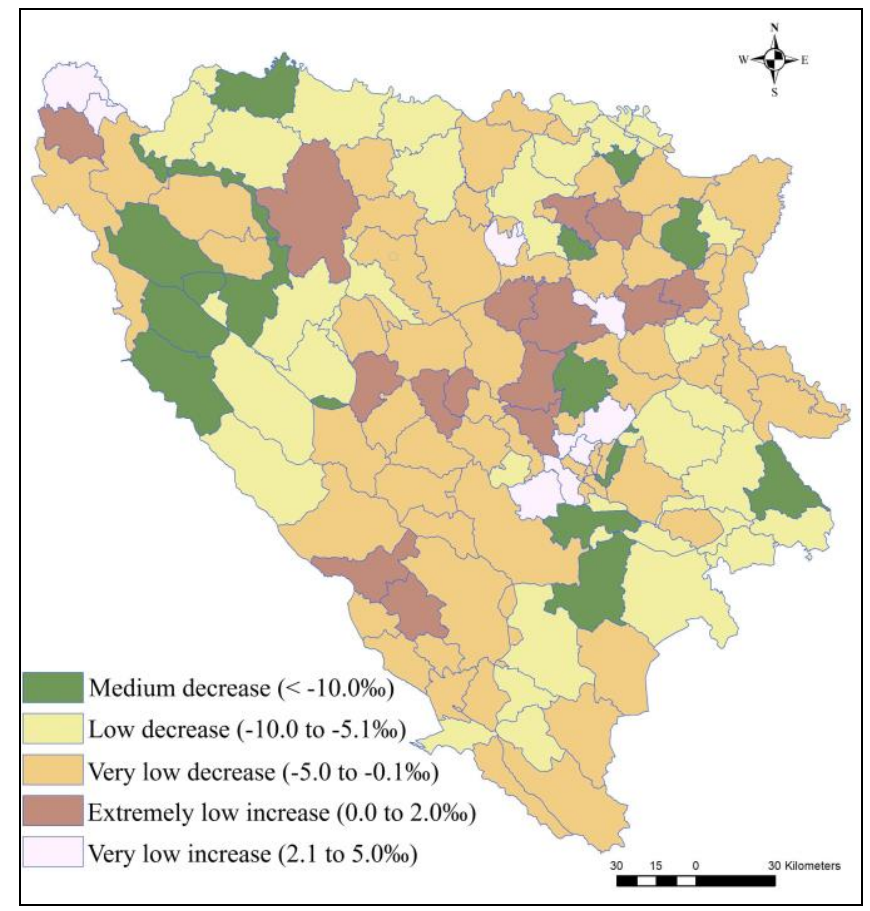

Figure 4. Municipalities by natural change rate, 2014-2018

We classified all municipalities in Bosnia and Herzegovina according to the marriage rate (showing the number of marriages per 1000 inhabitants) from 2014 to 2018 into 4 groups to confirm its impact on birth rates: very low (0.0-3.0\%) in 18 municipalities, low (3.1-5.0\%o) in 50, medium (5.1-7.0\%) in 59, and high (above $7.0 \%$ ) in 16 municipalities. Bosnia and Herzegovina is dominated by two groups of municipalities in terms of the marriage rate. The first one, with an average marriage rate $(5.1-7.0 \% 0)$, makes up $41.2 \%$, and the second, with a low marriage rate (3.1-5.0\%0), constitutes $35 \%$ of the total number of municipalities. Individual groups generally correspond to the spatial distribution of municipalities with low and very low birth rates. In the group with the lowest marriage rate, low birth rates were expected as well. This group, with an average of fewer than 2 marriages per 1,000 inhabitants, comprises 18 municipalities (12.6\%), including Rudo, Novo Goražde, Bosansko Grahouo, Rauno, Istočni Mostar and Istočni Druar. The high marriage rate group, a total of 16 municipalities (11.2\%), includes municipalities that stand out with their birth rates in Bosnia and Herzegovina. Marriage rates above 8\% belong to Bosanska Krupa, Brčko, Bužim and Trnovo (FBiH) (FZS, 2019b; ISR, 2019b). Trnovo (FBiH), which has attracted the immigration of young people in the last five years through various economic measures, is an exception in this group. This municipality with its 1,300 inhabitants 
belongs to a group of very small municipalities and lies in the immediate mountainous hinterland of the capital Sarajevo. In 2018 alone, it achieved a marriage rate of 8.5\%o (11 marriages).

We can associate low birth rates with the decline and low rates of marriage, and the lack of conditions and social and cultural norms in society that are characteristic of the developed countries of the European Union, where forms of single-parent families are much more common (Figure 5).

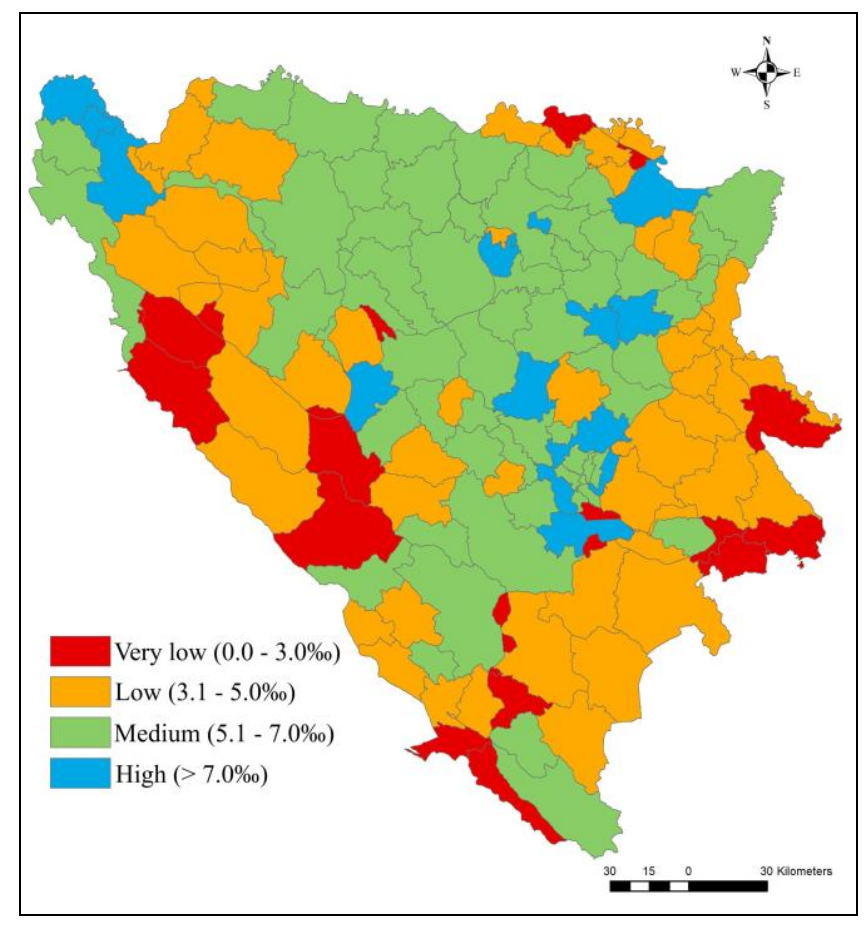

Figure 5. Municipalities by marriage rate, 2014-2018

All municipalities in Bosnia and Herzegovina are affected by a certain degree of population ageing, which is also reflected in the fact that none have type 1 population ageing (youth). Only 4 municipalities are characterized by type 2 (proper ageing); the group consists of three municipalities in the far northwest that have more rural than urban population and the highest proportions of the young population in Bosnia and Herzegouina (Bužim, Velika Kladuša, Cazin), and Sapna in northeast Bosnia and Herzegovina with the population aged 0-19 over $25 \%$. The first belt, with type 3 population ageing (old age), extends to the northeast of Gradačac and Zuornik, passes through the whole central Bosnia and ends in western Herzegovina, in Posušje and Ljubuški. The second belt is located in the northwest of the country and covers Bihać, Bosanska Krupa, Sanski Most and Ključ (a total of 49 municipalities of type 3). Type 4 (very old age) covers 43 municipalities, mainly in Herzegovina, and northern and northeastern Bosnia. The largest cities of Bosnia and Herzegovina are located in this belt: Sarajevo, Banja Luka, Tuzla, and Mostar. Type 5 (advanced old age) includes mostly municipalities of eastern Herzegovina, eastern Bosnia, and a large belt in the north of the country (41 municipalities). The last type of population ageing present in Bosnia and Herzegovina is type 6 (very advanced old age), which covers 6 municipalities characterized by high proportions of the old population and the lowest birth rates in Bosnia and Herzegovina. These are Bosansko Grahouo and Druar in the 
west, Kalinovik, Trnovo, and Istočni Stari Grad in the east, and Kupres. Figure 6 clearly shows two belts of municipalities with type 3 ageing (Gekić et al., 2019b).

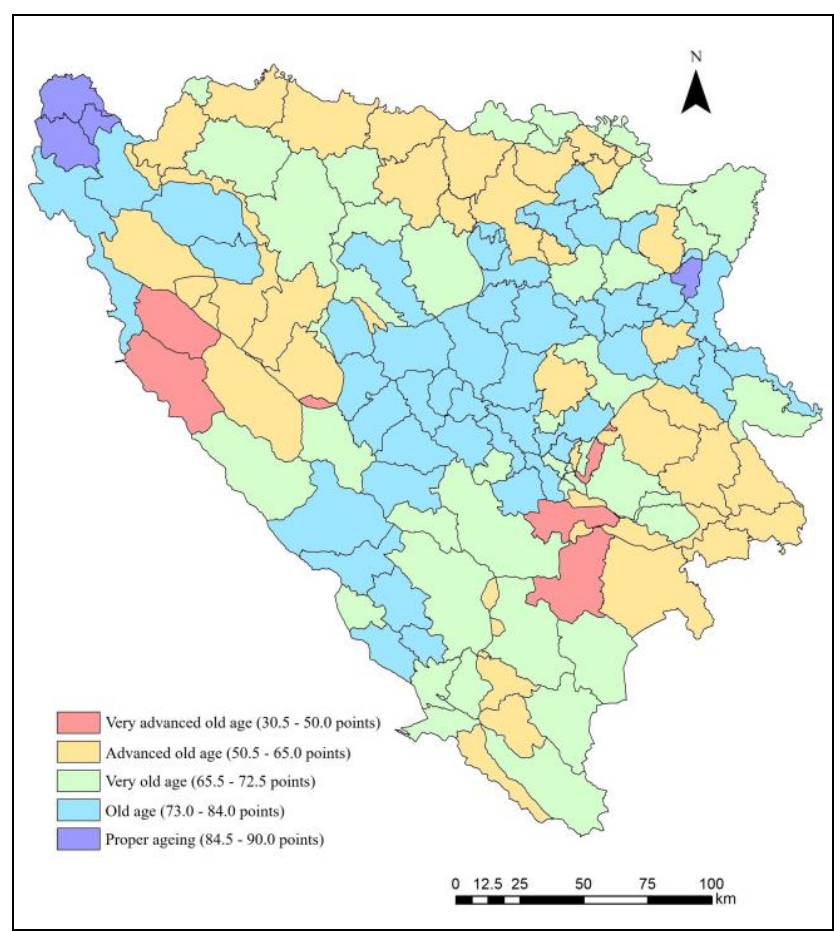

Figure 6. Types of population ageing in Bosnia and Herzegovina, 2014-2018

The overall net migration balance shows that since the Second World War, Bosnia and Herzegovina has been a country with high emigration rates. In the period 19481971, approximately 400,000 more people emigrated from Bosnia and Herzegouina than immigrated, mainly to Germany (unqualified workers), Serbia, Croatia and Slovenia. In the period 1971-1991, the total net migration balance was about $-300,000$, and in the period 1991-2018 even -1.2 million (BHAS, 1948-1991; BHAS, 2019). The negative migration balance of the last 30 years is one of the most important factors in the hidden geographies of population implosion in Bosnia and Herzegovina. Migrations resulting from the war, as well as the continuing economic ones, have been intensifying changes in the population, in particular in its structure (the most productive young population leaving). Extremely negative changes occurred in all spheres of life in Bosnia and Herzegovina during the period 1992-1995, which in the following 25 years led to a population implosion that rarely occurs in the world. Population emigration has led to a decrease in natural population change, to an ageing population, and to a decrease in the natural reproductive potential of the population. This trend continues, without exact and accurate data in the statistical agencies and national and regional governments. Unlike in the 1960s and 1970s, when emigrants were mostly unqualified workforce, emigrants today are far more qualified and educated. According to the results of the 2013 census, $9.6 \%$ of the population over the age of 15 had completed a higher level of education, which is significantly higher than in 1991, when this share was only 3.7\%, or in 1981 only 2.2\% (BHAS, 1948-1991; BHAS, 2016).

As for sustainable development, the question arises whether future generations will be able to withstand the burdens imposed by the ageing of the population in the field of health care, in the provision of funds for pensions, and in the field of social 
protection (Reynaud and Miccoli, 2018). The negative implications of hidden geographies of population implosion are visible in all pores of society, ranging from the pension system, health care and education systems to the labour market (reduction and ageing of the working contingent calling into question the country's faster economic development).

Family and family ties in Bosnia and Herzegovina still hold an important place in the lives of individuals-almost $90 \%$ of children are born within marriage (BHAS, 2017).

Young people in Bosnia and Herzegovina are economically and financially dependent on their parents, mostly because of their longer education, which prevents them in some professions from attaining professional status in society by their middle years. In addition, an increasing number of young people are unable to find suitable employment after graduation and are forced to build their lives in a parental home, where their independence and freedom remain unrealized (Žiga et al., 2015).

Based on the empirical indicators obtained through the survey which relate to the family in Bosnian society, the following can be concluded: Most young people in the household live with their parents $(73 \%)$ and siblings (27\%). Young people who are still in school or are unemployed are significantly more likely to live with parents between the ages of 15 and 22. The determination of young people in Bosnia and Herzegovina to plan family life is very pronounced; $88 \%$ of young people plan their future within the institution of marriage, and only a small percentage of them (3\%) plan to live in an extramarital union. Furthermore, a small number of young people plan to have a childless marriage (3\%) or see themselves as unmarried and childless in the future, and only $1 \%$ expect to be single parents. Young people over the age of 25 are more likely to see themselves in a marital union in the future, unlike young people aged 15-24. According to Flere et al. (2013), in Slovenia 61\% of young people plan to enter into marriage and in Croatia $76 \%$. It is characteristic that young people who have only completed secondary school education are more prone to get married in the near future than young people with higher education. The difference is more than $20 \%(37 \%: 16 \%)$. On the basis of the data from our survey, we can estimate the desired number of children in the population of Bosnia and Herzegovina (Table 2).

Table 2. Desired number of children in the population of Bosnia and Herzegouina

\begin{tabular}{|c|c|c|c|}
\hline Desired number of children & General population & $15-19$ years & 20-29 years \\
\hline 0 & 0.4 & 1.8 & 1.1 \\
\hline 1 & 4.5 & 11.7 & 7.8 \\
\hline 2 & 54.3 & 46.2 & 54.6 \\
\hline 3 & 30.5 & 33.3 & 29.1 \\
\hline 4 & 7.8 & 5.4 & 6.1 \\
\hline $5 \geq$ & 2.5 & 1.6 & 1.3 \\
\hline
\end{tabular}

According to the survey, our respondents have a smaller number of children than they would like to have. There is a significant disproportion between the number of children desired and the actual number. The desired number of children ranges from 2.2 among high school students (15-19) to 2.8 on average among the population, while the average number of live births is 1.7. Numerous socio-geographical changes in the position and status of the young population in the country have certainly contributed to this situation and the decrease in the number of children. The average number of 
children depends on the age group, with the age group 15-29 being particularly low in number.

Family is ranked high on the social value scale. $79 \%$ of respondents believe that a partner is needed for a successful and happy life, while the proportion of young people of the same opinion is $64 \% .61 \%$ of young people think it is important to have children. Young people deem that the best age to enter into marriage is between 26 and 27 years of age; the cause of delaying marriage until the late twenties should be sought in experiencing difficulties in reaching economic independence. Thus, young people attach considerable importance to completed educational process that provides financial security and material conditions, which are a key prerequisite for marriage. About $52 \%$ of young people do not attach importance to religion when choosing a spouse, and about $57 \%$ do not consider nationality relevant in this context. The most important factor in choosing a spouse for young people in Bosnia and Herzegouina is the personality (87.5\%), common interests (82\%), and then ethnic and religious affiliation. According to Yesilada et al. (2009), religion is a major source of both social values and social capital.

If we compare our data with the data of other studies, there is a certain difference. In the Bosnia and Herzegovina Youth Study, when selecting a spouse, young people placed common interests first $(84 \%)$, followed by personality $(82 \%)$, religious affiliation $(66 \%)$ and ethnic origin (58\%). Due to the prolonged education process and inadequate employment opportunities or the lack thereof, young people in Bosnia and Herzegovina under the pressure of uncertainty postpone their independence until the late twenties. A previous study on youth (Žiga et al., 2015) reported that $49 \%$ of young people wanted to leave the country, while a slightly earlier study by Halimić et al. (2013) warned that as many as $60 \%$ of young people wanted to leave Bosnia and Herzegouina.

Our research shows that the proportion of young people aged 15-29 who want to leave the country permanently is now a bit lower (46\%). The main reasons cited by young people for wanting to leave the country are quality of life (38\%), corruption (34\%), and the lack of perspective (23\%). It is concerning that $46 \%$ of young people want to leave the country forever, while $23 \%$ plan to stay abroad for more than 20 years (Figure 7). The desire to return has been expressed by $54 \%$ of young people. However, they plan to spend the most productive years elsewhere, which has wider social implications.

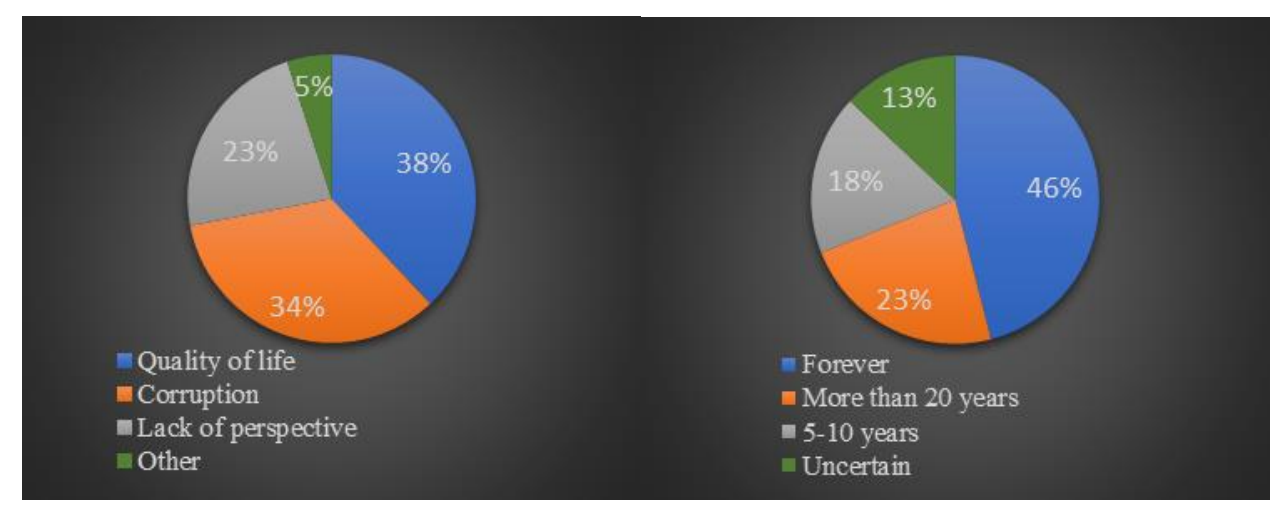

Figure 7. Reasons for wanting to leave the country and the desired length of time abroad 
In terms of taking steps towards leaving the country, most have not yet done anything to put their plan into action (57\%). Citizens of Bosnia and Herzegovina mostly want to emigrate to Germany (55\%), Austria (17\%), Switzerland (11\%), and Sweden (11\%). Most of them are very motivated to make an extra effort to learn a foreign language, although a high percentage (37\%) of respondents learnt foreign languages in school.

Approximately 87,500 Bosnians renounced their citizenship between 1998 and 2018. About two thirds of them renounced their citizenship in order to acquire German, Austrian, Slovenian, Croatian, Serbian, or Danish citizenship (Ministry of Human Rights and Refugees, 2019). The prevailing public discourse on migration creates the impression that it is not only a "desirable" but a "necessary" next step. The results of our study show a high proportion of young people who want to emigrate. The primary reasons for the desire to leave are the need to improve their living standards and find employment (Turčilo et al., 2019).

State budget expenditure for pensions and health care for the elderly will almost more than double by 2050. The number of people aged 75 and over will increase by $105 \%$ (218,000 people) in comparison with the year 2013; the overall share will rise from 5.9 to $8.1 \%$. According to UNDESA (2019), Bosnia and Herzegovina will have only 1,6 million people in 2100 , which is $53 \%$ less than in 2019 . All of this will put a heavy burden on the welfare and health care funds. With the increase in the number of elderly people, there is a growing need to provide a variety of formal care to this contingent of the population. Due to the decreasing number of children in families, also the number of those subject to social security contributions is decreasing (Gekić et al., 2019b).

\section{CONCLUSIONS}

All data show that unemployment is the number one problem for young people in Bosnia and Herzegovina. Over $60 \%$ of young people are unemployed, of which $13.4 \%$ have been unemployed for less than 12 months, half of them for over 2 years and one fifth for over 5 years. Almost half of the job seekers are young people (15-34 years). Over $50 \%$ of children with elementary education from poor families do not continue their education, while $10 \%$ of them do not have health insurance (Ministry of Civil Affairs of Bosnia and Herzegovina, 2019).

In addition to unemployment, inadequacy of the education system, the depressing political situation in the country and the lack of prospects for a better future have all caused the trend of mass emigration of young people to other countries. Existential problems of young people, which are mostly the result of long-term unemployment and temporary employment, have a strong impact on having fewer children than desired. Societies with an ageing population must confront this issues and adapt to the changes as quickly as possible (Kerbler, 2015). Reversing long-term ageing and low fertility remains problematic, given that the relevant policies may not pay dividends until the next generation reaches the working age (Rand Europe, 2005). Bosnia and Herzegovina will not be able to provide sufficient labour force from its own resources, but will have to focus on importing labour through economic coercion. In this sense, Bosnia and Herzegovina should consider its diaspora as one of the sources of revitalization. The diaspora needs to be supported in making the best out of their lives in the host 
countries while at the same time being encouraged to keep their identity strong and their relationship with Bosnia and Herzegovina productive (Halilovich et al., 2018). Recent demographic trends in Bosnia and Herzegovina cannot be stopped and reversed in a positive direction without deliberate, systematic long-term state intervention, from the local community to regional and state institutions. However, the aforementioned requires a general social consensus and strong political will of all key actors in Bosnian society, which will be extremely difficult to achieve.

A case from Scotland, where hidden geographies that exist through variations in household behaviour were not addressed effectively through different programmes (Mould and Baker, 2017), should serve as a reminder that Bosnia and Herzegovina's future population programmes and population policies should consider these hidden geographies of population implosion in relation to its citizens' system of values and not ignore them as before.

\section{ACKNOWLEDGEMENTS}

Peter Remenyi's work was supported by the Bolyai programme of the Hungarian Academy of Sciences and the ÚNKP-19-4 New National Excellence Program of the Ministry for Innouation and Technology.

\section{REFERENCES}

Agency for Statistics of Bosnia and Herzegovina 1948-1991. Censuses of population and households 1948, 1953, 1961, 1971, 1981, 1991. Sarajevo: BHAS.

Agency for Statistics of Bosnia and Herzegovina (2016). Census of Population, Households and Dwellings in Bosnia and Herzegovina 2013. Sarajevo: BHAS.

Agency for Statistics of Bosnia and Herzegovina (2018). Demography 2017, Thematic bulletin. Sarajevo: BHAS.

Agency for Statistics of Bosnia and Herzegovina (2019). Bosna i Hercegovina u brojevima 2019. Sarajevo: BHAS.

Akrap, A. 2002. Prostorni razmještaj stanouništua u Hruatskoj, Hruatska demografska $i$ demostrateška drama, ed. Pauletić, V., 32-70. Zagreb: A. G. Matoš.

Central Intelligence Agency (2019). The World Factbook 2019, Total fertility rates by country, CIA. Langley: World Factbook. Auailable at https://www.cia.gou/library/publications/the-world-factbook/fields/356.html (Accessed 15 December 2019).

Dumont, G. F. (2006). A Demographic Implosion In Europe? Lexicon: ambiguous and debatable terms regarding family life and ethical questions, 173-187. Front Royal, VA: Human Life International.

Flere, S., Klanjšek, R., Laurič, M., Kirbiš, A., Taučar, Krajnci, M., Diujak, M., Boroja T., Zagorc, B., and Naterer, A. (2013). Slovenian youth - Living in times of disillusionment, risk and precarity. Maribor: Centre for the Study of Post-Yugoslau Societies.

Friganouić, M. A. (1992): Promjene u dinamici stanouništua Hruatske 1981-1991 kao funkcija urbanizacije. Hruatski geografski glasnik: 54 (1): 63-74. 
Gekić, H., and Bidžan-Gekić, A. (2019a). Urban Hierarchy Inside a Divided Urban System of Bosnia and Herzegovina, 1st Istanbul International Geography Congress Proceedings Book 2019, Istanbul University Press. Istanbul: 492-510.

Gekić, H., Bidžan-Gekić, A., Mirić, R., and Drešković, N. (2019b). Spatial Differentiation of the Age Structure of a Population in Bosnia and Herzegovina, Proceedings of International Scientific Symposium New Trends In Geography 2019, Macedonian Geographical Society. Ohrid: 215-226.

Gelo, J., Akrap, A., and Čipin, I. (2005). Temeljne značajke demografskog razuoja Hruatske. Zagreb: Ministarstuo obitelji, branitelja i međugeneracijske solidarnosti.

Halilovich, H. (2012). Trans-local Communities in the Age of Transnationalism: Bosnians in Diaspora. International Migration Journal: 50 (1): 162-178.

Halilovich, H., Hasić, J., Karabegović, Dž., Karamehić-Muratović, A., and Oruč, N. (2018). Mapping the Bosnian-Herzegovinian Diaspora. Sarajevo: Ministry of Human Rights and Refugees of Bosnia and Herzegovina.

Halimić, Š., Koštrebić, K., and Neimarlija, N. (2013). Na putu ka politici prema mladima FBiH. Analiza stanja i potreba mladih u FBiH. Sarajevo: Institut za razuoj mladih KULT

Helms, E. (2013). Innocence and victimhood. Gender, nation, and women's activism in postwar Bosnia-Herzegovina. Madison, WI: University of Wisconsin Press.

Hoff, A. (2011). The drivers of population ageing in Central and Eastern Europe: Fertility, mortality and migration. Population ageing in Central and Eastern Europe - Societal and policy implications, ed. A. Hoff, 1-10. Aldershot: Ashgate.

Institute for Statistics of FBiH (2019a). Demographic statistics 2018, Statistical bulletin. Sarajevo: FZS.

Institute for Statistics of $\mathrm{FBiH}$ (2019b). Estimate of the total population for the Federation of Bosnia and Herzegovina, by cantons 2013-2019. Sarajevo: FZS.

Institute of Statistics of Republika Srpska (2019b). Demographic statistics 2019, Statistical bulletin. Banja Luka: ISR.

Institute of Statistics of Republika Srpska, (2019a). Population estimates. Banja Luka: ISR.

Kadušić, A., Suljić, A. (2018). Migration and Demographic changes: The Case of Bosnia and Herzegovina, European Journal of Geography: 9(4): 75-86.

Kerbler, B. (2015): Population Aging in Slovenia - A Spatial Perspective. Acta geographica Slovenica, 55 (2): 305-316.

Lesthaeghe, R., and Neels, K. (2002). From the first to the second demographic transition: An interpretation of the spatial continuity of demographic innouation in France, Belgium and Switzerland. European Journal of Population: 18: 325-360.

Lukic, T., Stojsauljevic, R., Durdeu, B., Nad, I., and Dercan, B. (2012). Depopulation in the Western Balkan Countries. European Journal of Geography: 3 (2): 6-23.

Ministry of Civil Affairs of Bosnia and Herzegovina (2019). Data on Youths in Bosnia and Herzegovina. Sarajevo: Ministry of Human Rights and Refugees of Bosnia and Herzegovina. 
Ministry of Human Rights and Refugees of Bosnia and Herzegovina (2019). Information on the status of emigrants from Bosnia and Herzegovina. Sarajevo: Ministry of Human Rights and Refugees of Bosnia and Herzegovina.

Mould, R., and Baker, K. (2017). Uncovering hidden geographies and socio-economic influences on fuel poverty using household fuel spend data: A meso-scale study in Scotland. Indoor and Built Environment: 26 (7): 914-936.

Nejašmić, I. (2008). Stanouništuo Hruatske: demogeografske studije i analize. Zagreb: Hruatsko geografsko društuo.

Nejašmić, I., and Toskić, A. (2000). Razmještaj stanouništua u Republici Hruatskoj - dio općih demografskih i društueno-gospodarskih procesa. Geoadria: 5: 93-104.

Putkaradze, M., and Putkaradze, L. (2019). The Intra-Regional Originalities of Population's Dynamics of Mountain Regions of Georgia. European Journal of Geography: 10 (2): 107-117.

Research and Development Europe (2005). Population Implosion? Low Fertility and Policy Responses in the European Union. Research Brief: RAND Europe. Auailable at https://www.rand.org/content/dam/rand/pubs/research_briefs/2005/RAND_RB912 6.pdf (Accessed 14 December 2019).

Reynaud, C., and Miccoli, S. (2018). Depopulation and the Aging Population: The Relationship in Italian Municipalities, Sustainability, 10 (4): 1004

SURS (2017). Data. Ljubljana: Statistični urad Republike Slovenije. Available at http://pxweb.stat.si/pxweb/dialog/statfile1.asp. (Accessed 5 December 2019).

Turčilo, L., Osmić, A., Šadić, S., Dudić, A., Kapidžić, D., and Žiga, J. (2019). Studija mladi Bosna i Hercegovina 2018/2019. Sarajevo: Friedrich-Ebert-Stiftung.

United Nations Department of Economic and Social Affairs/Population Division (2019). World Population Prospects, 2019. New York: UNDESA. Auailable at https://population.un.org/wpp/Download/Standard/Population/ (Accessed 12 November 2019).

Van Bavel, J. (2007). Sub-replacement fertility in the west before the baby boom: Past and current perspectives. Population Studies: 64 (1): 1-18.

Van de Kaa, D. J. (1996). Anchored narratives: The story and findings of half a century of research into the determinants of fertility. Population Studies: 50 (3): 389-432.

Vuillamy, E. (2012). The war is dead, long live the war: Bosnia - The reckoning. London: Vintage.

Wertheimer-Baletić, A. (1982). Demografija - Stanouništuo i ekonomski razuitak. Zagreb: Informator.

Yesilada, B., Noordijk, P., Webster, C. 2009. Religiosity and Social Values of the Cypriots. Social Compass: 56 (1): 15-34.

Žiga, J., Turčilo, L., Osmić, A., Bašić, S., Džananouić Miraščija, N., Kapidžić, D., and Brkić Šmigoc, J. (2015). Studija mladi Bosna i Hercegovina, Sarajevo: Friedrich-EbertStiftung.

Zwierzchowski, J., and Tabeau, E. (2010). The 1992-95 War In Bosnia And Herzegouina: Census-Based Multiple System Estimation Of Casualties' Undercount, International Research Workshop on 'The Global Costs of Conflict' The Households in Conflict 
Network (HiCN) and The German Institute for Economic Research (DIW Berlin). Berlin, 1-25. Auailable at

https://www.icty.org/x/file/About/OTP/War_Demographics/en/bih_casualty unde rcount conf_paper 100201.pdf (Accessed 3 November 2019). 